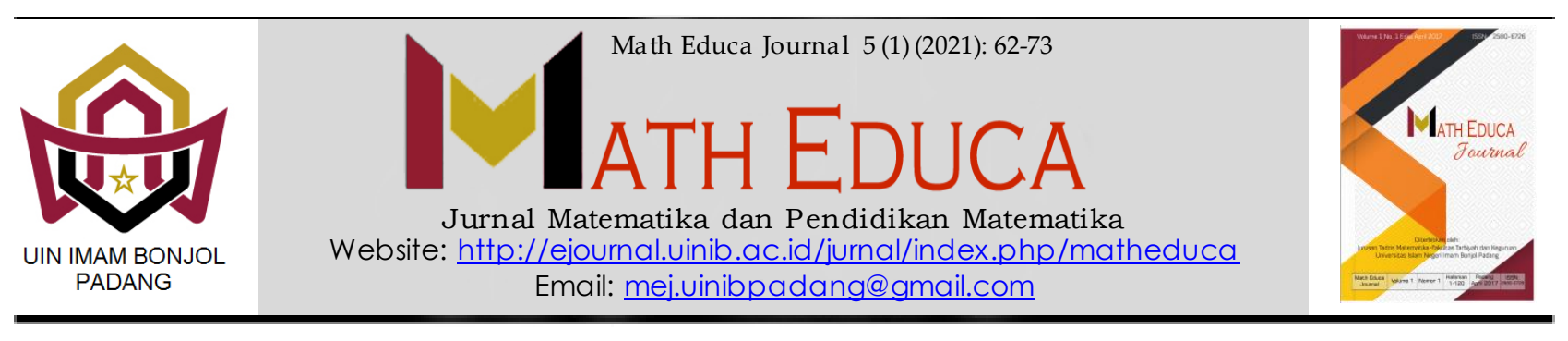

\title{
KETERAMPILAN KOMUNIKASI MATEMATIS SISWA PADA MATERI BANGUN RUANG SISI DATAR DITINJAU DARI SELF EFFICACY
}

\author{
'Nur Asri Melawati S, ${ }^{2}$ Erdawati Nurdin \\ 1,2 Pendidikan Matematika, Fakultas Tarbiyah dan Keguruan, Universitas Islam Negeri Suska Riau \\ E-mail: ' nurasrimelawati@gmail.com, ${ }^{2}$ erdawati.nurdin@uin-suska.ac.id
}

Received: February 2021; Accepted: March 2021; Published: April 2021

\begin{abstract}
Mathematical communication skills are one of the competencies that students must have in the $21^{\text {st }}$ century. This study aims to anylize and describe students' mathematical communication skills in terms of self efficacy on the polyhedrons material. The research used descriptive qualitative methods. The subjects were 9 grade students of An nashichah private junior high school selected purposively. Data was collected through online test, questionnaires and interviews using WhatsApp. The data analyzed through 3 stages, namely data reduction, data presentation and conclusions. The results showed that the students' mathematical communication skills were low. When viewed from students' self efficacy, high self efficacy students have high mathematical communication. Meanwhile, low and moderate self efficacy students have low mathematical communication skills. The use of Whatsapp media is not able to support students mathematical communication skill and self efficacy. The tachers need to design learning media to help students improve their mathematical communication skills and self efiicacy.
\end{abstract}

Keywords: Analyze, mathematical communication skills, self efficacy

\section{Abstrak}

Di abad 21, siswa harus memiliki keterampilan komunikasi matematis yang baik. Tujuan penelitian ini adalah menganalisis dan menggambarkan keterampilan komunikasi matematis siswa berdasarkan self efficacy pada materi bangun ruang sisi datar. Penelitian ini menggunakan metode kualitatif. Berdasarkan tingkat eksplanasinya, penelitian ini termasuk penelitian deskriptif. Sembilan (9 ) siswa kelas VIII SMPS Tahfidz An Nashichah dipilih sebagai subjek penelitian. Data dikumpulkan melalui teknik tes, angket dan teknik wawancara. Penelitian dilaksanakan secara daring melalui aplikasi whatssapp. Tahapan analisis data yang dilakukan adalah reduction (reduksi data), data presentation (penyajian data) and conclusions (penarikan kesimpulan). Data yang dikumpulkan dan dianalisis menunjukkan masih rendahnya keterampilan komunikasi matematis siswa. Jika dipandang dari self efficacy siswa, hanya siswa kategori self efficacy tinggi yang memiliki keterampilan komunikasi matematis yang tinggi, lainnya rendah. Penggunaan media Whatsapp kurang mampu menunjang keterampilan komunikasi dan self efficacy siswa. Guru perlu mendesain media pembelajaran yang dapat meningkatkan keterampilan komunikasi matematis dan self efficacy siswa.

Kata kunci: Analisis, keterampilan komunikasi matematis, self efficacy

\footnotetext{
${ }^{*}$ Corresponding author.

Peer review under responsibility UIN Imam Bonjol Padang.

(C) 2021 UIN Imam Bonjol Padang. All rights reserved.

p-ISSN: 2580-6726

e-ISSN: 2598-2133
} 


\section{PENDAHULUAN}

Bialik \& Fadel (2015) menyebutkan bahwa terdapat keterampilan yang wajib dimiliki siswa pada pembelajaran abad 21, disebut 4C's, yaitu creativity, critical thinking and problem solving, communication and collaboration. Oleh karena itu, penting bagi siswa untuk memiliki keterampilan komunikasi matematis yang baik. Keterampilan komunikasi matematis adalah kemampuan menyampaikan, menerima dan memahami gagasan/ide matematis secara cermat, analitis dan kritis, baik secara lisan maupun tulisan.

Sebagaimana yang dirangkum oleh National Council of Teachers of Mathematic (NCTM, 2000) menyatakan bahwa komunikasi matematika adalah cara berbagi ide dan mengklarifikasi pemahaman. Melalui komunikasi, ide menjadi objek refleksi, penyempurnaan, diskusi, dan perubahan. Ketika siswa ditantang untuk mengkomunikasikan hasil pemikiran mereka kepada orang lain secara lisan atau tertulis, mereka belajar untuk menjelaskan, meyakinkan dan menulis dengan bahasa matematika yang tepat. Penjelasan yang disampaikan harus mencakup argumen dan alasan matematis yang logis, bukan hanya deskripsi atau ringkasan prosedural. Pada keterampilan komunikasi ini siswa dituntut untuk memahami, mengelola dan menciptakan komunikasi yang efektif dalam berbagai bentuk dan isi secara lisan, tulisan dan multimedia. Dengan komunikasi siswa dapat mengembangkan kemampuan dalam berbicara, menuangkan ide/gagasan matematis, meningkatkan kosa kata, dan kemampuan belajar yang lebih baik.

Penyelesaikan masalah matematika memerlukan keterampilan komunikasi matematis (OECD, 2013). Dengan membuat model matematika dapat membantu memahami dan memnyelesaikan masalah. Kemudian setelah masalah dapat diselesaikan, maka perlu dikomunikasikan dan disajikan disertai penjelasan dan justifikasi.

Saat ini mutu pendidikan Indonesia masih tergolong rendah. Salah satu indikator yang menunjukkan mutu pendidikan di tanah air cenderung masih rendah adalah hasil penilaian internasional tentang prestasi siswa yaitu Survei Trends International Mathematics and Science Study (TIMSS). Hasil survei TIMSS pada tahun 2015 Indonesia menduduki peringkat 44 dari 49 peserta pada bidang matematika dengan perolehan skor 397 dimana rata-rata TIMSS berkisar di skor 500 (Mullis et al., 2015).

Berdasarkan hasil survei tersebut, kita perlu mengecek kembali bagaimana sebenarnya keterampilan matematis siswa di lapangan dan meninjau kembali apakah kelemahan tersebut juga terletak pada rendahnya keterampilan komunikasi matematis siswa. Dengan menganalisis bagaimana keterampilan komunikasi matematis siswa, kita dapat mengetahui apa yang telah dipelajari siswa mengenai materi bangun ruang datar dan sejauh mana siswa telah memiliki keterampilan komunikasi matematis pada materi tersebut. Melalui kegiatan menganalisis dan dan menafsirkan keterampilan komunikasi matematis ini, guru dapat mendiagnosis kelemahan siswa dalam menyelesaikan soal keterampilan komunikasi matematis untuk dijadikan sebagai bahan evaluasi perbaikan program pembelajaran yang telah dilakukan. Dengan demikian, kita dapat menyusun tindakan atau upaya apa yang harus dilakukan untuk memperbaiki keterampilan komunikasi matematis siswa.

Geometri merupakan salah satu materi yang berkaitan dengan komunikasi matematis. Sebagaimana yang disebutkan oleh Budiarto \& Artiono (2019) bahwa geometri melatih keterampilan komunikasi matematis siswa melalui konjektur, diskusi, eksplorasi dan investigasi. Geometri memperoleh bagian terbesar dalam pembelajaran matematika 
dibandingkan materi lainnya, yaitu $41 \%$ (Supriadi, 2015).

Sayangnya, kemampuan siswa pada materi geometri masih rendah. Berdasarkan data dari Kemendikbud, persentase siswa yang menjawab benar dari hasil ujian nasional (UN) siswa SMPS Tahfidz An Nashichah pada tahun ajaran 2018/2019 pada materi geometri dan pengukuran yaitu 34, 32\% (Kemendikbud, 2019). Dari hasil tersebut, peneliti ingin melihat apakah hasil yang diperoleh oleh siswa SMPS Tahfidz An Nashichah tersebut juga disebabkan oleh keterampilan komunikasi matematis yang rendah. Untuk itu, peneliti melakukan penelitian untuk mengetahui kemampuan komunikasi matematis siswa pada materi bangun ruang sisi datar.

Penelitian Pajares \& Miller (1994) menunjukkan hubungan signifikan performa matematika siswa dengan self efficacy. Peneliti menduga bahwa self efficacy juga akan mempengaruhi keterampilan komunikasi matematis siswa. Self efficacy adalah kepercayaan diri seseorang terhadap keterampilannya dalam melaksanakan tugas (Bandura, 1997; MZ \& Risnawati, 2015). Siswa yang memiliki keyakinan diri biasanya dimiliki oleh siswa sehingga kemungkinan bahwa self efficacy berdampak positif terhadap keterampilan komunikasi matematis siswa. Muklis dan Sanhabi (Shodiqin, Sukestriyatno, et al., 2020) menyebutkan bahwa self efficacy atau self confidence dapat mempengaruhi keterampilan komunikasi matematis. Hendriana dan Kadarisma menambahkan bahwa seseorang yang memiliki self efficacy yang tinggi akan terampil berkomunikasi matematis (Hendriyana \& Kadarisma, 2019). Self efficacy dapat menunjang keterampilan mereka dalam merumuskan konsep, menyatakan gagasan matematika dan mempertajam gagasan untuk membuat orang lain yakin. Artinya, seseorang dengan self efficacy yang tinggi akan memiliki kemampuan komunikasi matematis yang baik. Oleh sebab itu peneliti ingin menganalisis bagaimana keterampilan komunikasi matematis siswa SMPS Tahfidz An Nashichah. Penelitian ini juga meninjau bagaimana kemmapuan komunikasi matematis siswa dari sudut pandang self efficacy yang mereka miliki.

\section{METODE PENELITIAN}

\section{Jenis Penelitian}

Sesuai dengan tujuan penelitian ini yaitu mendeskripsikan bagaimana keterampilan komunikasi matematis siswa. Data yang diperoleh kemudian dianalisisi secara mendalam guna memahami makna mengenai keterampilan komunikasi matematis siswa tersebut. Jadi, penelitian ini termasuk jenis penelitian deskriptif kualitatif. Tujuan penelitian deskriptif ialah menjelaskan dan memetakan fakta-fakta sesuai cara pandang dan kerangka berpikir tertentu (Mahmud, 2011). Pada penelitian kualitatif, data dianalisis secara induktif yang lebih menekankan pada makna dibandingkan generalisasi (Sugiyono, 2013).

\section{Waktu dan Tempat Penelitian}

Penelitian ini dilakukan pada semester genap tahun ajaran 2019/2020 di SMPS Tahfidz An Nashichah Batam. Dikarenakan adanya pandemi, maka penelitian dilakukan secara daring melalui aplikasi WhatsApp.

\section{Subjek Penelitian}

Sembilan (9) orang dari 14 siswa kelas VIII SMPS Tahfidz An Nashichah dipilih sebagai subjek penelitian. Keempat belas (14) siswa tersebut diberikan angket untuk melihat tingkat self efficacy. Kemudian siswa dibagi menjadi 3 kategori yaitu siswa dengan self efficacy tinggi, self efficacy sedang dan self efficacy rendah. Selanjutnya, dipilih 3 orang siswa dari masing-masing kategori untuk menjadi subjek penelitian.

\section{Prosedur}

Penelitian ini dimulai dengan memberikan angket yang bertujuan untuk mengukur tingkat self efficacy. Empat belas siswa tersebut kemudian dibagi menjadi 3 
kategori, yaitu siswa dengan self efficacy tinggi, sedang dan self efficacy rendah. Selanjutnya dipilih 3 siswa dari masing-masing kategori sebagai subjek penelitian.

$$
\text { Penelitian dilanjutkan dengan }
$$

memberikan soal tes keterampilan komunikasi matematis kepada siswa. Jawaban siswa kemudian diberi skor sesuai dengan rubrik penskoran untuk mengetahui kemampuan komunikasi matematis siswa. Selanjutnya siswa diwawancarai untuk memperoleh makna lebih mendalam dan memperkuat hasil yang diperoleh dari jawaban tes siswa. Hasil tes dan wawancara ini dianalisis. Terakhir, peneliti menarik kesimpulan mengenai keterampilan komunikasi matematis siswa berdasarkan self efficacy.

\section{Teknik dan Intrumen Pengumpulan Data}

Teknik pengumpulan data yang digunakan yaitu teknik angket, tes dan wawancara. Teknik angket digunakan untuk memperoleh data self efficacy. Teknik tes digunakan untuk memperoleh data mengenai kemampuan komunikasi matematis siswa. wawancara yang digunakan untuk memperkuat dan mengetahui alasan-alasan dari jawaban tes dan angket siswa.

Instrumen penelitian yang digunakan yaitu soal tes, lembar angket self efficacy dan pedoman wawancara. Soal tes yang diberikan terdiri atas 3 soal uraian yang disusun berdasarkan indikator kemampuan komunikasi matematis yang diungkapkan oleh Roesdiana (Hendriana et al., 2017), yaitu:

Tabel 1. Indikator Keterampilan Komunikasi

\section{Matematis}

\begin{tabular}{clc}
\hline No. & \multicolumn{1}{c}{ Indikator } & Skor maks \\
\hline 1. & $\begin{array}{l}\text { Membuat model matematika } \\
\text { dari situasi yang disajikan }\end{array}$ & 5 \\
2. & $\begin{array}{l}\text { Menyelesaikan model } \\
\text { matematika bentuk gambar }\end{array}$ & 4 \\
3. & $\begin{array}{l}\text { Merangkai pertanyaan dan } \\
\text { menyelesaikannyadari } \\
\text { gambar }\end{array}$ & 4 \\
& Skor Ideal & 13 \\
\hline
\end{tabular}

Lembar angket self efficacy menggunakan skala Likert dengan empat item pilihan, yaitu sangat setuju, setuju, tidak setuju dan sangat tidak setuju. Angket ini disusun berdasarkan indikator self efficacy yang diungkapkan oleh Bandura (1997), yaitu dimensi magnitude, strength dan generality. Instrumen ke tiga yang digunakan adalah pedoman wawancara. Wawancara ini dilakukan secara daring menggunakan video call pada aplikasi whatsapp.

\section{Teknik Analisis Data}

Teknik analisis data yang digunakan adalah teknik analisis data menurut Miles \& Huberman (1994) yaitu:

1. Reduksi data yaitu merangkum, memilih hal-hal yang pokok, memfokuskan pada hal yang penting, dicari tema dan polanya dan membuang yang tidak perlu agar data yang telah direduksi akan memberikan gambaran yang lebih jelas.

2. Penyajian data, pada langkah ini data terorganisasikan, tersusun dalam pola hubungan, sehingga semakin mudah dipahami.

3. Penarikan kesimpulan pada penelitian kualitatif yang diharapkan merupakan temuan baru yang sebelumnya belum pernah ada. Temuan dapat berupa deskriptif atau gambaran suatu objek yang sebelumnya masih remang-remang sehingga setelah diteliti menjadi lebih jelas dan temuan ini dapat berupa hubungan kausal atau interaktif, hipotesis atau teori.

\section{HASIL PENELITIAN DAN PEMBAHASAN}

\section{Hasil}

Berdasarkan hasil angket yang diperoleh, diketahui bahwa siswa kelas VIII SMPS Tahfidz An Nashichah memiliki tingkat self efficacy sedang. Rata-rata kemampuan komunikasi matematis siswa adalah 5,36 dari skor ideal 13. Skor ini menunjukkan bahwa 
secara umum kemampuan komunikasi matematis siswa masih rendah.

Sebagaimana telah disebutkan bahwa data pada penelitian ini dilakukan dalam 3 tahap, yaitu : reduksi data, penyajian data dan penarikan kesimpulan. Berikut dipaparkan secara ringkas setiap tahapannya.

Reduksi Data

Pada tahapan ini, peneliti akan memaparkan hasil wawancara dengan 3 orang dari 9 subjek yang terpilih berdasarkan tingkat self efficacy siswa, yang masing-masing siswa mewakili setiap kategori. Adapun petikan wawancara peneliti dengan subjek disimbolkan dengan $P$ sebagai peneliti dan inisial subjek sebagai subjek.

Soal nomor 1 merupakan soal dengan indikator membuat model matematika dari situasi yang diberikan dan meyelesaikannya. Adapun bunyi soalnya ialah: "Sebuah prisma alasnya berbentuk segitiga siku-siku dengan sisi miring $26 \mathrm{~cm}$ dan salah satu sisi sikusikunya $10 \mathrm{~cm}$, dengan tinggi prisma $12 \mathrm{~cm}$. Gambarkanlah bentuk prisma yang sesuai dengan pernyataan soal dan hitunglah luas permukaan dari prisma tersebut! ". Adapun jawaban subjek dan hasil wawancara peneliti dengan 3 subjek mewakili setiap indikator adalah sebagai berikut:

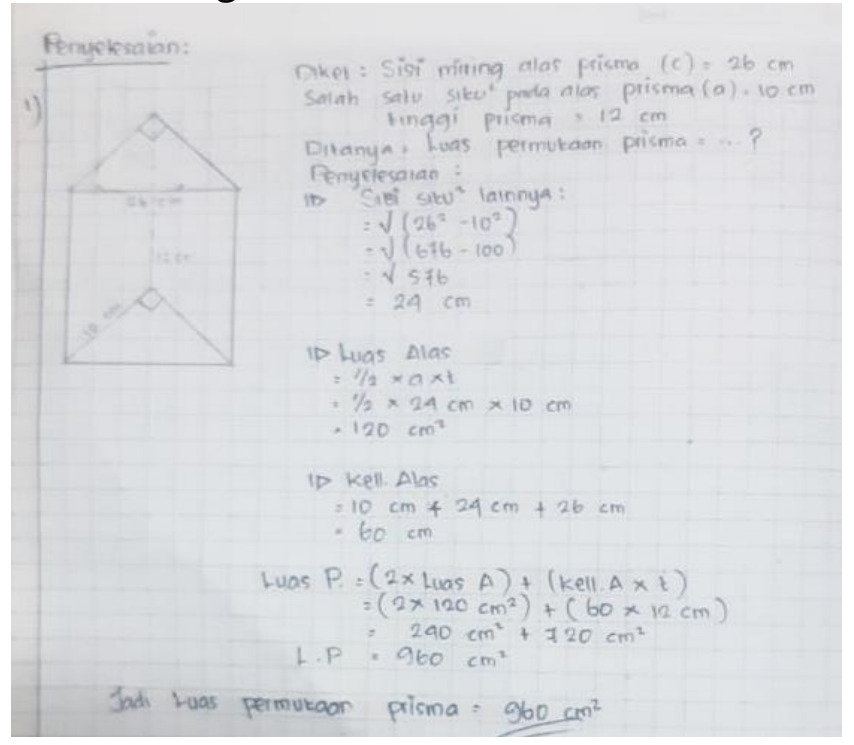

Gambar 1. Jawaban Subjek S-6 Soal Nomor 1
Jawaban pada gambar 1 merupakan jawaban subjek S-6 yang mewakili kategori self efficacy tinggi. Hasil tes tersebut diperkuat dengan hasil wawancara yang dilakukan oleh peneliti kepada subjek S-6. Berikut petikan wawancara peneliti (P) dengan subjek S-6 Terkait soal nomor 1:

P : "Coba kamu jelaskan apa yang kamu gambar pada soal nomor 1."

S-6 : "Prismanya prisma segitiga kan kak. Alasnya segitiga siku-siku yang sisi miringnya $26 \mathrm{~cm}$ kak terus salah satu sisi siku-sikunya $10 \mathrm{~cm}$ saya buat jadi alas segitiganya kak. Terus tinggi primanya $12 \mathrm{~cm}$ kak"

P : "Lalu bisa kamu simpulkan jawaban dari nomor 1 kamu?"

S-6 : "Kesimpulannya sebelum cari luas permukaan cari sisi segitiga dulu, terus cari luas permukaan dan keliling segitiga barulah cari luas permukaan prismanya kak"

Dari gambar 1 dan petikan wawancara terlihat bahwa subjek S-6 mampu menyelesaikan persoalan dengan sempurna. Subjek S-6 memperoleh skor sempurna yaitu 5 . Subjek S-6 mampu menjelaskan gambar yang dibuat dan menyatakan informasi yang diperoleh dari soal serta menyelesaikannya. Hal ini menunjukkan bahwa subjek S-6 mampu menyatakan situasi ke dalam model matematika (dalam hal ini menggambar) dan meyelesaikannya. Hal tersebut diperkuat dengan wawancara antara peneliti dengan subjek S-6.

Selanjutnya, siswa dengan kategori self efficacy sedang yang diwakili oleh subjek S-14. Berikut hasil jawaban dan wawancara subjek S14: 


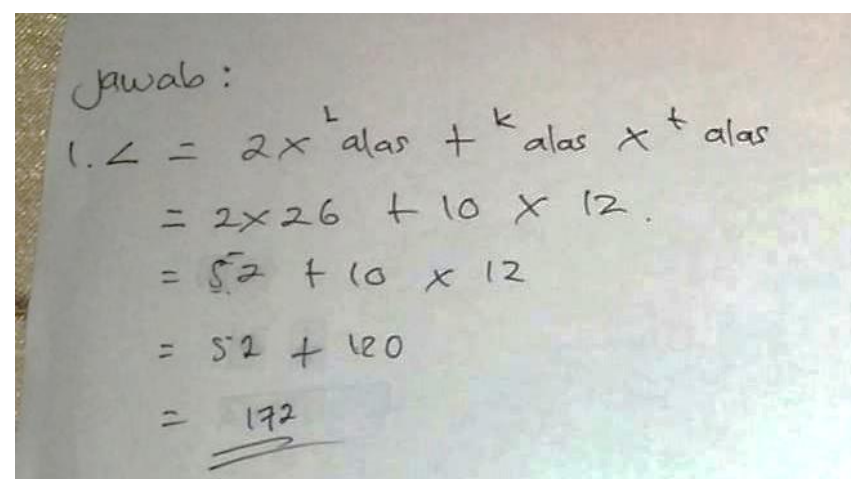

Gambar 2. Jawaban Subjek S-14 Soal Nomor 1

Hasil tes tersebut diperkuat dengan hasil wawancara yang dilakukan oleh peneliti kepada subjek S-14. Berikut petikan wawancara peneliti (P) dengan subjek S-14 Terkait soal no 1:

P :"Soal nomor 1 kan diminta menggambar, kenapa kamu tidak buat gambarnya?"

S-14 : "saya kurang paham kak, jadi saya tidak menggambar prismanya. Saya langsung masukkan angka yang diketahui itu ke rumusnya"

P :"Kenapa?”

S-14 :"Belajarnya online kak, pakai WA aja. Dikasih tugas dari buku untuk dikerjakan. Jadi gak ngerti"

P : "Rumus yang kamu tuliskan sudah benar, tetapi angka yang kamu masukkan salah. Harusnya kamu mencari dulu panjang sisi segitiga yang belum diketahui. Kamu dapat menggunakan teorema Phytagoras. Kamu paham gak tentang teorema Phytagoras?"

S-14 :"Gak terlalu kak, sedikit bingung dengan teorema Phytagoras"

P : "Kenapa?"

S-14 : "Sudah lama belajarnya kak, lupa"

Dari gambar 2 terlihat bahwa subjek S-

14 belum memahami soal dengan baik, sehingga tidak mampu memahami soal (mengidentifikasi informasi yang terdapat pada soal) dan belum bisa menuliskan model matematika (menggambar prisma). Subjek S14 melakukan kesalahan dalam mencari luas permukaan prisma. Pembelajaran daring yang dilakukan melalui whatsapp menyebabkan subjek kurang memahami materi dan tidak mampu menggambar prisma (membuat model matematika), sehingga subjek tidak dapat menyelesaikan soal dengan benar. Subjek juga terindikasi tidak memahami konsep keliling segitiga dan teorema Phytagoras yang merupakan materi prasyarat yang dibutuhkan untuk menyelesaikan soal tersebut. Subjek binggung dan lupa tentang materi tersebut Hal ini menunjukan bahwa S-14 belum mampu membuat model matematika dari situasi yang disajikan dan meyelesaikannya.

Terakhir, siswa dengan kategori self efficacy rendah yang diwakili oleh subjek S-7. Berikut hasil jawaban dan wawancara subjek S-

7:

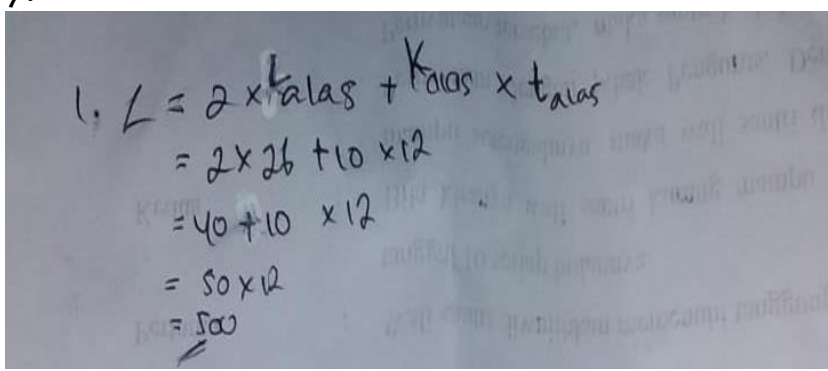

Gambar 3. Jawaban Subjek S-7 Soal Nomor 1

Hasil tes tersebut diperkuat dengan hasil wawancara yang dilakukan oleh peneliti kepada subjek S-7. Berikut petikan wawancara peneliti ( $P$ ) dengan subjek S-7 Terkait soal nomor 1:

P : "Kenapa kamu tidak menggambar prismanya?."

S-7 : "Saya tidak tau cara menggambarnya kak"

P : " "Informasi apa yang diketahui dan ditanya dari soal tersebut?

S-7 : "Sisi miringnya 26 kak, sisi siku-siku 10 cm sama tinggi prisma kak $12 \mathrm{~cm}$ "

P : :Jadi bagaimana kamu ngerjainnya?"

S-7 : "Masukkan angka-angkanya ke rumus prisma kak"

P : : "Terus untuk mencari keliling segitiga alas kan kurang satu sisi lagi. Kenapa tidak dicari?"

S-7 : "Gak terlalu paham kak"

Gambar 3 memperlihatkan bahwa subjek S-7 telah berusaha menyelesaikan soal 
cerita yang disajikan. Subjek S-7 belum mampu menyelesaikan soal nomor 1 dengan tepat. Kesalahan yang dilakukan oleh subjek S-7 hampir sama dengan yang dilakukan oleh subjek S-14, dan diperparah dengan ketidaktelitian ketika proses perkalian.

Subjek S-7 belum mampu menyelesaikan soal dengan baik dan belum mampu membuat model matematika dalam bentuk gambar yang diminta pada soal. Jadi, subjek S-7 juga belum mampu membuat model matematika dari situasi yang disajikan dan meyelesaikannya.

Penyajian Data

Setelah tahapan reduksi data, dilanjutkan dengan tahap penyajian data. Tabel berikut menyajikan kemampuan komunikasi matematis siswa berdasarkan self efficacy.

Tabel 2. Keterampilan Komunikasi Matematis Siswa berdasarkan Self Efficacy

Indikator Keterampilan Komunikasi Matematis

1. Membuat model matematika dari situasi yang disajikan menyelesaikannya darigambar

3. Menyelesaikan model matematika bentuk gambar

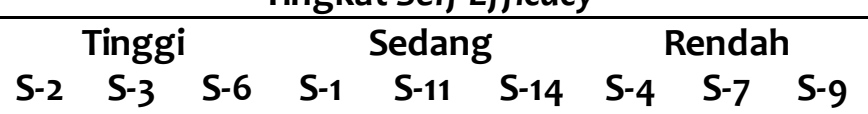

$\begin{array}{llllllllll}\text { Skor } & 3 & 4 & 5 & 3 & 2 & 2 & 2 & 2 & 2\end{array}$

\begin{tabular}{cccccccccc} 
Rata-rata & 4 & \multicolumn{3}{c}{2,33} & & 2 & \\
Skor & 3 & 4 & 2 & 2 & 0 & 1 & 0 & 1 & 0 \\
Rata-rata & 3 & & & 1 & & & 0,33 &
\end{tabular}

$\begin{array}{llllllllll}\text { Skor } & 2 & 2 & 2 & 1 & 0 & 2 & 0 & 2 & 0\end{array}$

$\begin{array}{llll}\text { Rata-rata } & 2 & 1 & 0,67\end{array}$

Rata-rata Keseluruhan

3

1,44

1

Dari Tabel 2 dapat dilihat bahwa secara umum keterampilan komunikasi matematis siswa masih rendah. Ditinjau dari self efficacy siswa, untuk siswa dengan kategori self efficacy tinggi mampu menyelesaikan indikator 1 dengan baik, sedangkan indikator 2 dan 3 masih terdapat banyak kesalahan. Siswa dengan kategori self efficacy sedang dan rendah masih belum memiliki keterampilan komunikasi yang baik, mereka melakukan kesalahan di semua indikator keterampilan komunikasi matematis.

Untuk memudahkan dalam menarik kesimpulan, maka dilakukan proses coding/ pengodean. Berikut hasil pengodean kemampuan siswa dalam menyelesaikan soal kemampuan komunikasi matematis.
Tabel 3. Pengodean Keterampilan Komunikasi Matematis Siswa Berdasarkan Self Efficacy

\begin{tabular}{ccccc}
\hline $\begin{array}{c}\text { Self } \\
\text { Efficacy }\end{array}$ & $\begin{array}{c}\text { Kode } \\
\text { Siswa }\end{array}$ & \multicolumn{3}{c}{$\begin{array}{c}\text { Indikator Keterampilan } \\
\text { Komunikasi Matematis }\end{array}$} \\
\cline { 3 - 5 } & & 1 & 2 & 3 \\
\hline Tinggi & S-2 & $V$ & $V$ & $V$ \\
& $S-3$ & $V$ & $V$ & $\times$ \\
& S-6 & $V$ & $V$ & $\times$ \\
Sedang & S-1 & $V$ & $V$ & $\times$ \\
& S-11 & $\times$ & $\times$ & $\times$ \\
& S-14 & $\times$ & $\times$ & $\times$ \\
Rendah & $S-4$ & $\times$ & $\times$ & $\times$ \\
& S-7 & $\times$ & $\times$ & $\times$ \\
& S-9 & $\times$ & $\times$ & $\times$ \\
\hline
\end{tabular}

Keterangan:

$\checkmark \quad$ : mampu menyelesaikan dengan baik

$\times \quad$ : tidak mampu/melakukan kesalahan 


\section{Penarikan Kesimpulan}

Siswa dengan self efficacy tinggi cukup mampu menyelesaikan soal tes kemampuan komunikasi matematis dengan baik yaitu pada indikator membuat model matematika dari situasi yang disajikan dan menyelesaikannya. Untuk indikator menyelesaikan model matematika bentuk gambar yang diberikan siswa dengan self efficacy tinggi masih mengalami kesalahan perhitungan pada jawaban soal. Pada indikator merangkai pertanyaan dari gambar dan menjawabnya, siswa kategori self efficacy tinggi masih mengalami kesalahan dalam menjawab soal dan belum mampu menyelesaikan soal pada indikator tersebut dengan benar. Secara umum, siswa dengan self efficacy tinggi sudah mampu mengidentifikasi informasi yang ada pada soal dengan baik, mampu menggambar dengan benar dan menguasai materi prasyarat yang dibutuhkan untuk menyelesaikan soal. Namun dalam penyelesaian soal, masih ada beberapa yang kekeliruan dalam menggambarkan, menghitung dan menuliskan angka yang diketahui pada soal.

Siswa dengan self efficacy sedang masih melakukan kekeliruan dalam menjawab soal di semua indikator. Secara umum, siswa dengan self efficacy sedang belum dapat mengidentifikasi informasi yang ada pada soal dengan baik, belum mampu menentukan strategi penyelesaian soal dengan baik dan masih belum menguasai materi prasyarat yaitu menentukan keliling segitiga dan teorema phytagoras. Dalam penyelesaian soal, masih ada beberapa yang kurang teliti dalam menghitung dan menuliskan angka yang diketahui pada soal. Dan masih belum sepenuhnya paham materi bangun ruang sisi datar.

Siswa dengan self efficacy rendah belum mampu menyelesaikan soal tes keterampilan komunikasi matematis dengan baik di semua indikator. Secara umum, siswa dengan self efficacy rendah belum maksimal dalam mengidentifikasi informasi yang ada pada soal dengan baik, masih belum menguasai materi prasyarat. Dalam penyelesaian soal, masih ada beberapa yang kekeliruan dalam menghitung dan menuliskan angka yang diketahui pada soal.

\section{Pembahasan}

Berdasarkan angket self efficacy yang telah disebarkan kepada subjek penelitian kelas VIII di SMPS Tahfidz An Nashichah Batam yang berjumlah 14 siswa menunjukan bahwa setiap subjek penelitian memiliki tingkat self efficacy yang berbeda-beda. Sebagian besar siswa memiliki self efficacy sedang. Adapun keberagaman self efficacy yang diperoleh, sebagaimana dijelaskan oleh Bandura bahwa empat sumber informasi utama yang dapat mengembangkan self efficacy atau kemampuan diri adalah pengalaman diri sendiri (keberhasilan ataupun kegagalan), pengalaman keberhasilan dan kegagalan orang lain, persuasi verbal dan keadaan fisiologis (Bandura, 1997; Hendriana et al., 2017). Self efficacy tidak terbentuk dengan sendirinya, namun melalui proses. Self efficacy akan Nampak dari perilaku seseorang. Terdapat langkah-langkah yang harus dijalani seseorang agar dapat benar-benar percaya dengan kemampuannya dalam melaksanakan tugas (MZ \& Risnawati, 2015).

Secara umum, keterampilan komunikasi matematis siswa masih rendah. Namun, mereka sudah mampu membuat model matematika dari situasi yang diberikan dan menyelesaikannya dengan baik. Sesuai dengan yang disimpulkan oleh (Haniatusaadah \& Basir, 2020) bahwa keterampilan komunikasi matematis siswa SMP berada pada kategori tinggi untuk indikator mempresentasikan benda nyata, gambar dan diagram dalam bentuk model matematika. Berdasarkan hasil wawancara dengan siswa, diketahui bahwa guru di SMPS Tahfidz An Nachihah cukup sering memberikan soal cerita yang 
mengharuskan siswa membuat model matematika untuk menyelesaikan soal tersebut.

Berdasarkan self efficac, siswa yang memiliki self efficacy tinggi juga mempunyai keterampilan komunikasi matematis yang baik di beberapa indikator. Mereka sudah bisa membuat model matematika dari situasi yang disajikan dan menyelesaikannya. Selain itu, siswa dengan self efficacy tinggi juga dapat menyelesaikan model matematika bentuk gambar yang diberikan, namun masih kesulitan dalam membuat pertanyaan dari soal. Siswa kategori self efficacy sedang dan rendah memiliki keterampilan komunikasi matematis yang rendah. Mereka melakukan kesalahan di semua indikator. Mereka belum mampu menyusun model matematika dari situasi yang diberikan dan menyelesaikannya, melakukan kekeliruan dalam membuat model matematika dari gambar yang disajikan, serta belum terampil dalam merangkai pertanyaan dari soal. Hasil penelitian ini sejalan dengan yang dilakukan oleh Juhrani et al. (2017). Hasil penelitian tersebut menyimpulkan bahwa siswa dengan self efficacy sedang dan rendah belum bisa mengungkapkan ide-ide matematis secara maksimal. Dengan demikian, baik siswa dengan self efficacy tinggi, sedang ataupun rendah belum memiliki keterampilan komunikasi matematis yang baik. Hal ini dapat diartikan bahwa self efficacy tidak memberikan pengaruh yang besar terhadap keterampilan komunikasi matematis siswa. Hasil tersebut bertentangan dengan penelitian (Hamidah, 2012; Hendriana \& Kadarisma, 2019; Ramadhani \& Harahap, 2020) yang menyatakan bahwa self efficacy berpengaruh signifikan terhadap keterampilan komunikasi matematis siswa.

Pada penelitian ini, faktor selain self efficacy siswa berdampak lebih besar terhadap keterampilan komunikasi matematis siswa kelas VIII SMPS Tahfidz An-nashichah. Sebagaimana hasil penelitian Fitria \&
Handayani (2020) menyimpulkan bahwa keyakinan diri siswa berpengaruh 37,69\%, sedangkan faktor selain kepercayaan diri mempengaruhi keterampilan komunikasi matematis siswa lebih besar, yaitu 53,9\%. Lemahnya keterampilan komunikasi ini dapat diakibatkan oleh pembelajaran yang dilakukan kurang efektif. Materi bangun ruang sisi datar ini diajarkan bertepatan pada masa pandemi Covid-19 yang mengharuskan seluruh sekolah di Indonesia melakukan pembelajaran secara daring. Proses pembelajaran yang dilakukan secara daring menggunakan aplikasi whatsapp. Penelitian Daheri et al. (2020) menyimpulkan bahwa aplikasi whatsapp kurang efektif digunakan sebagai media pembelajaran daring. Perlu dilakukan inovasi dalam pembelajaran daring (Utami et al., 2020), menggunakan media pembelajaran yang bervariasi (Annur \& Hermansyah, 2020). Guru harus kreatif dalam mendesain media pembelajaran yang lebih efektif, misalnya mengembangkan video pembelajaran yang menarik (Nurdin et al., 2019) atau menggunakan aplikasi e-learning seperti Edmodo (Ompusunggu \& Sari, 2019). Salah satu cara agar siswa dapat mengembangkan keterampilan komunikasi matematis selama pembelajaran adalah dengan menerjemahkan, mengaplikasikan dan melakukan penilaian hasil secara matematis melalui diskusi dan menyampaikan/mengkomunikasi gagasan dan pendapat yang berkaitan dengan masalah (Stacey, 2011). Lebih baik lagi jika masalah yang dihadirkan sesuai dengan konteks yang dekat dengan kehidupan siswa. Salah satunya konteks tabuik untuk pembelajaran materi bangun ruang sisi datar (Fitriza \& Gunawan, 2019).

Penelitian ini memiliki keterbatasan. Penelitian ini dilakukan secara daring dengan bantuan aplikasi whatsapp sehingga tingkat kecurangan siswa dalam mengerjakan soal yang diberikan cukup tinggi. Salah satu masalah dalam pembelajaran daring adalah 
kecurangan atau siswa yang menyontek (Bedford et al., 2011; Jr et al., 2013; Khan \& Balasubramanian, 2009; Kocdar et al., 2018). Untuk itu, perlu taktik dan trik penilaian untuk melakukan evaluasi yang dapat dipertangung jawabkan.

\section{SIMPULAN DAN SARAN}

Berdasarkan data yang diperoleh dan dianalisis, diperoleh kesimpulan bahwa: (1) keterampilan komunikasi matematis siswa masih rendah pada materi bangun ruang sisi. (2) berdasarkan self efficacy, siswa kategori self efficacy tinggi mempunyai keterampilan komunikasi matematis yang tinggi, namun masih kesulitan dalam merangkai pertanyaan menjawabnya. Siswa pada kategori self efficacy sedang dan rendah, keterampilan komunikasi matematisnya masih tergolong rendah.

\section{REFERENSI}

Annur, M. F., \& Hermansyah. (2020). Analisis kesulitan mahasiswa pendidikan matematika dalam pembelajaran daring pada masa pandemi Covid-19. Jurnal Kajian, Penelitian Dan Pengembangan Kependidikan, 11(2), 195-201. https://doi.org/10.31764

Bandura, A. (1997). Self-efficacy: the exercise of control. Worth Publisher.

Bedford, D. W., Gregg, J. R., \& Clinton, M. S. (2011). Preventing online cheating with technology: a pilot study of remote proctor and an update of its use. Journal of Higher Education Theory and Practice, 11(2), 41-58.

Bialik, M., \& Fadel, C. (2015). Skills for the 21 st century: what should students learn? (Issue May). Center for Curriculum Redesign.

Budiarto, M. T., \& Artiono, R. (2019). Geometri dan permasalahan dalam pembelajarannya (suatu penelitian meta analisis). JUMADIKA: Jurnal Magister Pendidikan Matematika, 1(1), 9-18. https://doi.org/10.30598/jumadikavoliiss1y ear2019page 9 -18

Daheri, M., Juliana, Deriwanto, \& Amda, A. D. (2020). Efektifitas whatsapp sebagai media belajar daring. Jurnal Basicedu, 3(2), 524-532. https://doi.org/10.31004/basicedu.v4i4.44 5

Fitria, V., \& Handayani, I. (2020). Kemampuan komunikasi matematis berdasarkan self efficacy. Transformasi: Jurnal Pendidikan Matematika Dan Matematika, 4(1), 189202. https://doi.org/10.36526/tr.v4i1.906

Fitriza, R., \& Gunawan, I. (2019). Tabuik dalam Pembelajaran Bangun Ruang dengan Pendidikan matematika Realistik (PMR). Math Educa Journal, 2(1), 13-22. https://doi.org/10.15548/mej.v2i1.31

Hamidah. (2012). Pengaruh self efficacy terhadap kemampuan komunikasi matematik. Prosiding Seminar Nasional, Penelitian, Pendidikan Dan Penerapan MIPA, Juni, 79-84.

Haniatusaadah, S., \& Basir, M. A. (2020). Analisis kemampuan komunikasi matematis siswa sekolah menengah pertama pada materi aljabar. Math Educa Journal, 4(1), 167-172.

Hendriana, H., \& Kadarisma, G. (2019). Selfefficacy dan kemampuan komunikasi matematis siswa SMP. JNPM (Jurnal Nasional Pendidikan Matematika), 3(1), 153-164.

https://doi.org/10.33603/jnpm.v3i1.2033

Hendriana, H., Rohaeti, E. E., \& Sumarmo, U. (2017). Hard Skills dan Soft Skills Matematik Siswa. PT Refika Aditama.

Jr, J. M., Fitterer, A., Brazier, E., Leonard, J., \& 
Brown, A. (2013). Examining online college cyber cheating methods and prevention measures. The Electronic Journal of E-Learning, 11(2), 139-146.

Juhrani, Suyitno, H., \& Khumaedi. (2017). Analisis kemampuan komunikasi matematis berdasarkan self-efficacy siswa pada model pembelajaran Mea. Unnes Journal of Mathematics Education Research, 6(2), 251-258.

Kemendikbud. (2019). Laporan Hasil Ujian Nasional: Kementerian Pendidikan Dan Kebudayaan. In Diakses Agustus 12, 2020.

Khan, Z. R., \& Balasubramanian, S. (2009). Students go click, flick and cheat: echeating, technologies and more. Journal of Academic and Business Ethics, 1-26.

Kocdar, S., Karadeniz, A., Peytcheva-Forsyth, R., \& Stoeva, V. (2018). Cheating and plagiarism in e-assessment: students' perspectives. Open Praxis, 10(3), 221-235. https://doi.org/10.5944/openpraxis.10.3.87 3

Mahmud. (2011). Metode penelitian pendidikan. Pustaka Setia.

Miles, M. B., \& Huberman, A. M. (1994). Qualitative data analysis (Second Ed). Sage Publication.

Mullis, I. V. S., Martin, M. O., Foy, P., \& Arora, A. (2015). Timss 2015 International Results in Science Saved. Distribution of Science Achievement. http://timss2015.org/timss2015/science/studentachievement/distribution-of-scienceachievement/

MZ, Z. A., \& Risnawati. (2015). Psikologi pembelajaran matematika. Aswaja Pressindo.

NCTM. (2000). Principles and standards for school mathematics.
Nurdin, E., Ma'aruf, A., Amir, Z., Risnawati, R., Noviarni, N., \& Azmi, M. P. (2019). Pemanfaatan video pembelajaran berbasis Geogebra untuk meningkatkan kemampuan pemahaman konsep matematis siswa SMK. Jurnal Riset Pendidikan Matematika, 6(1), 87-98. https://doi.org/10.21831/jrpm.v6i1.18421

OECD. (2013). The PISA 2012 assesment framework-mathematics, reading, science and problem solving knowledge and financial literacy. In OECD. https://doi.org/10.1007/978-3-319-126883_31

Ompusunggu, V. D. K., \& Sari, N. (2019). Efektifitas penggunaan e-learning berbasis edmodo terhadap kemampuan komunikasi matematika. Jurnal Curere, 3(2), 58-66. https://doi.org/10.36764/jc.v3i2.250

Pajares, F., \& Miller, M. D. (1994). 10.1.1.587.2720. Journal of Educational Psychology, 86(2), 193-203.

Ramadhani, R., \& Harahap, J. Y. (2020). Pengaruh self efficacy terhadap kemampuan komunikasi matematis melalui pembelajaran dengan menggunakan aplikasi SPSS. Logaritma: Jurnal Ilmu-IImu Pendidikan Dan Sains, 8(01), 27-40. https://doi.org/10.24952/logaritma.v8io1.2 382

Shodiqin, A., Sukestriyatno., Wardono., Isnarto., \& Waluya, S.B. (2020). Mathematical communication profile in solving probability problems reviewed by self efficacy of prospective mathematics teachers. Universal Journal of Educational Research . 8(10), 4661-4670. https://doi.org/10.13189/ujer.2020.081035

Stacey, K. (2011). The PISA View of Mathematical Literacy in Indonesia. 2(2), 95-126. 
Sugiyono. (2013). Penelitian pendidikan: pendekatan kuantitatif dan kualitatif dan r\&d. Alfabeta.

Supriadi, N. (2015). Pembelajaran geometri berbasis Geogebra sebagai upaya meningkatkan kemampuan komunikasi matematis. Al-Jabar: Jurnal Pendidikan Matematika, 6(2), 99-110.

Utami, Y. P., Alan, D., \& Cahyono, D. (2020). Studi at home: analisis kesulitan belajar matematika pada proses pembelajaran daring. Jurnal Ilmiah Matematika Realistik (JI-MR), 1(1), 20-26. http://jim.teknokrat.ac.id/index.php/pendi dikanmatematika/article/view/252/84

https://doi.org/10.24042/ajpm.v6i2.20 